\title{
Effect of Inorganic Fertilizer Micro-dosing and Weed Management Regimes on Finger Millet Productivity in Uganda
}

\author{
Joseph Ekwangu ${ }^{1}$, John Steven Tenywa ${ }^{2}$, Jenifer Bisikwa ${ }^{2}$, Charles Andiku ${ }^{1}$, Paul Anguria ${ }^{1}$, \\ Monday Moses Paga ${ }^{2}$, Deborah Lillian Nabirye ${ }^{2}$, Michael Adrogu $\operatorname{Ugen}^{1} \&$ Nelson Wanyera ${ }^{1}$ \\ ${ }^{1}$ National Semi Arid Resources Research Institute (NaSARRI), Soroti, Uganda \\ ${ }^{2}$ Department of agricultural production, Makerere University, Kampala, Uganda \\ Correspondence: Joseph Ekwangu, National Semi Arid Resources Research Institute, Serere, P.O. Box 56, Soroti, \\ Uganda. E-mail: jekwangu@gmail.com
}

Received: August 18, 2020

doi:10.5539/jas.v12n12p134
Accepted: October 19, $2020 \quad$ Online Published: November 15, 2020

URL: https://doi.org/10.5539/jas.v12n12p134

This research is financed by Harnessing Opportunities for Productivity Enhancement of Sorghum and Millets II (HOPE II) and $M^{c}$ KNIGHT Foundation.

\begin{abstract}
Finger millet yields in farmers' fields are low primarily due to low soil fertility and poor weed management. Fertilizer application could be one of the key strategies used to address the problem. However, due to high cost of fertilizer, its utilization has been limited to very few farmers in the country. Consequently, a study was conducted in Kuju sub-county, Amuria district in Eastern Uganda during 2016 long and short rains to determine the effect of micro dosing and weeding time on finger millet performance and weed growth. The experiment was laid out in a randomized complete block design in a split plot treatment structure. Weeding times constituted the main plot [weeding at 20 DAS (days after sowing), 30 DAS, 45 DAS, and $20 \& 45$ DAS (double weeding)], while fertilizer rates $\left(\mathrm{N} 16.6 \mathrm{~kg} \mathrm{ha}^{-1}+\mathrm{P}_{2} \mathrm{O}_{5} 10.6 \mathrm{~kg} \mathrm{ha}^{-1} ; \mathrm{P}_{2} \mathrm{O}_{5} 10.6 \mathrm{~kg} \mathrm{ha}^{-1} ; \mathrm{N} 16.6 \mathrm{~kg} \mathrm{ha}^{-1} ; \mathrm{N}_{0}+\mathrm{P}_{0}\right.$, and $\mathrm{N} 83 \mathrm{~kg} \mathrm{ha}^{-1}+\mathrm{P}_{2} \mathrm{O}_{5} 52 \mathrm{~kg}$ $\mathrm{ha}^{-1}$ ) constituted the sub plots. Results of this study revealed that the interaction between weeding at 45 DAS and fertilizer micro-dosing significantly $(\mathrm{P}<0.05)$ reduced weed biomass $\left(7.7 \times 10^{-4} \mathrm{~kg} \mathrm{ha}^{-1}\right)$ without significant increase in finger-millet grain yield. Interaction of fertilizer micro-dosing $\left(\mathrm{N} 16.6 \mathrm{~kg} \mathrm{ha}^{-1}+\mathrm{P}_{2} \mathrm{O}_{5} 10.6 \mathrm{~kg} \mathrm{ha}^{-1}\right)$ with weeding once at 20 DAS recorded the highest $\left(2292 \mathrm{~kg} \mathrm{ha}^{-1}\right)$ finger millet grain yield with significant $(\mathrm{P}<0.05)$ reduction in days to finger millet flowering. Therefore, it is recommended that fertilizer micro-dosing at $\mathrm{N} 16.6 \mathrm{~kg}$ $\mathrm{ha}^{-1}+\mathrm{P}_{2} \mathrm{O}_{5} 10.6 \mathrm{~kg} \mathrm{ha}^{-1}$ and weeding once at 20 DAS can be used to control weeds and enhance finger-millet productivity.
\end{abstract}

Keywords: full dose, fertilizer micro-dosing, weeds growth, timing of weeding

\section{Introduction}

Weeds and crop plants compete for limited supplies of soil nutrients especially nitrogen, phosphorus and potassium in the soil. In many agricultural systems around the world, competition from weeds is one of the major factors reducing crop yield and farmers' income (Berkowitz, 1988). This makes soil fertility management complex and therefore requires integrated approach (ICRISAT, 2013; Asargew \& Shibabawu, 2014).

Weeds are better competitors for nutrients than crops because of their more efficient root system and fast growth (Knight et al., 2017). Adequate fertility combined with effective weed management is important in maximizing finger millet grain yield. Finger millet $\mathrm{N}$ uptake is dependent on many factors including weed species and density, the rate and formulation of applied $\mathrm{N}$ fertilizer. Understanding interactions among finger millet, $\mathrm{N}$ applied and weeds is important in developing weed management strategies (Menegat \& Nilsson, 2019) and also soil fertility management (Opole et al., 2013; Asargew \& Shibabawu, 2014). Therefore, weeds are of economic importance to farmers and one of the major constraints to worldwide crop production. They deprive the crop plants of essential nutrients, water and light; plants become weak and consequently give poor yields (ICRISAT, 2013).

Blackshaw et al. $(2002,2003)$ reported fertilizer application method to have influence on weed population and reported that point fertilizer application reduced weed population by $25-63 \%$ across locations in Niger. This is 
because when fertilizer is applied around the root zone of the plant, $\mathrm{N}$ and $\mathrm{P}$ uptake is increased and consequently increased nitrogen and other nutrient use efficiency. This further reduces $\mathrm{N}$ losses and access by weeds (ICRISAT, 2013; Ekwangu et al., 2020). Therefore, there is need to develop a weed management plan that will increase nutrient use efficiency by the plant and reduce nutrient access by the weeds. Though Finger millet is known to be one of the most efficient crops in utilizing nitrogen in the soil hence indicating high nitrogen use efficiency (NUE) (Gupta et al., 2017), its yields has been reduced by weeds. It can only be achieved if weed control is done at critical finger millet growth stage (Knight et al., 2017) mainly at the initial stages of finger millet growth. At this early growth stage, finger millet growth is slow favoring weed growth and hence competition for sunlight, nutrient and water (Gupta et al., 2014; Knight et al., 2017). Yield loss due to weed interference with the normal growth of a plant accounts for $29.2 \%$ when no control measures are applied, however, lower yield loss (12.8\%) are recorded when weed control measures are applied (Asargew \& Shibabawu, 2014). Therefore, to reduce these negative effects of weeds on crop production, intensive application of weed control methods should be optimized.

Research however, recommends weeding millet twice, at 20 days after sowing (DAS) and 45 DAS (Esele, 1989; Wanyera, 2007). This recommendation is not affordable by the majority of the small holder finger millet farmers who often weed once because of the competing needs they are commonly faced with (Okoboi et al., 2012). Therefore, there is need to develop an integrated weed and nutrient management technologies to enhance finger millet production in the crop livestock farming system in the semi-arid region of eastern Uganda

\section{Materials and Methods}

\subsection{Study Site}

\subsubsection{Weather and Altitude}

This study was conducted in Kuju sub-county, Amuria district in Eastern Uganda which is located at $02^{\circ} 02^{\prime} \mathrm{N}$ $33^{\circ} 39^{\prime} \mathrm{E}$ and $1140 \mathrm{~m}$ above sea level with flat to gentle slope (UBOS, 2010). This area experiences mean annual rainfall of $1200 \mathrm{~mm}$ which is distributed in a bimodal pattern. The months of March to June and August to October or November receive substantial amount of precipitation, while months of January, February, and December are drier with very little precipitation. The area experiences mean annual minimum and maximum temperature of $15^{\circ} \mathrm{C}$ to $36^{\circ} \mathrm{C}$, respectively (UBOS, 2010).

\subsubsection{Soil Properties}

The soils at the experimental site are predominantly sandy loam and these suggests that the soils are often free draining and susceptible to loss of plant nutrients especially $\mathrm{N}$ and $\mathrm{P}$. Laboratory analysis of the soils at the experimental site also revealed that $\mathrm{N}$ was $0.00 \%, \mathrm{P}$ was $1.13 \mathrm{mg} \mathrm{kg}^{-1}$ and the $\mathrm{pH}$ ranged from 5.1 to 5.2 . These findings indicated that $\mathrm{N}$ and $\mathrm{P}$ were below the critical level of $\mathrm{N}(0.25 \%)$ and $\mathrm{P}\left(15 \mathrm{mg} \mathrm{kg}^{-1}\right)$.

\subsection{Treatments, Experimental Design and Crop Husbandry}

The treatments comprised of; weeding by hand hoeing at 20 days after sowing (DAS), 30 DAS, 45 DAS and double weeding (20 and 45 DAS) as main plot treatments, while $\mathrm{N} 16.6 \mathrm{~kg} \mathrm{ha}^{-1}+\mathrm{P}_{2} \mathrm{O}_{5} 10.6 \mathrm{~kg} \mathrm{ha}^{-1} ; \mathrm{P}_{2} \mathrm{O}_{5} 10.6$ $\mathrm{kg} \mathrm{ha}^{-1} ; \mathrm{N} 16.6 \mathrm{~kg} \mathrm{ha}^{-1} ; \mathrm{N}_{0}+\mathrm{P}_{0}$ and $\mathrm{N} 83 \mathrm{~kg} \mathrm{ha}^{-1}+\mathrm{P}_{2} \mathrm{O}_{5} 53 \mathrm{~kg} \mathrm{ha}^{-1}$ as the sub plot treatments. The design was laid out in a randomized complete block design (RCBD) with a split plot arrangement. Land was prepared by ploughing with an ox-plough twice before planting. Finger millet was planted by dibbling into a well pulverized field using blunt sticks and later covered with soil. At 20 days after sowing, finger millet was thinned out to a spacing of $0.3 \mathrm{~m}$ by $0.1 \mathrm{~m}$ between rows and plants, respectively. Each plot measured 3 by $3 \mathrm{~m}$. SEREMI II finger millet variety was used, while Triple Super Phosphate (TSP) and Urea were used as the inorganic source of $\mathrm{P}$ and N, respectively and three farmer sites were used as replicates. Triple Super Phosphate was applied in the planting hole at planting and urea was incorporated in the soil in between the finger millet lines as a side dress. Triple super phosphate was chosen over other P sources because it's a non-compound fertilizer which could easily be used to determine the effect of $\mathrm{P}$ on weed and finger millet performance.

\subsection{Data Collection}

Data was recorded on average tiller number per plot, growth vigor, plant height, days to $50 \%$ flowering and time to physiological maturity. Tillering of finger millet was assessed at 45 days after sowing (DAS). In situ sampling was done within each plot; where by five inner rows were selected by leaving two or three rows on either side of the plot. In each row, the $11^{\text {th }}$ plant from the border plants from either ends of the row, were considered for determination of tiller number (Rebetzkeaf et al., 2012). 
Growth vigor of finger millet plants, defined as "an active, healthy and well balanced growth of a plant" (Houghton Mifflin Co, 2007), was measured at 45 and 60 DAS using a scale of 0-4 as described by Hatier et al. (2014). Where, $0=$ Plant is dead/did not germinate; poor $=1=$ plant has no tiller; Low $=2=$ Plant has less than two tillers; Moderate $=3=$ Plant has 2-3 tillers; Vigorous $=4=$ plant has above three tillers. Growth vigor was assessed in situ using the same fore-mentioned finger millet plants used for tillering assessment.

Days to $50 \%$ flowering of finger millet was determined starting from when the crop was at $20 \%$ flowering. A Quadrant of $1 \times 1 \mathrm{~m}$ was randomly thrown within the inner rows of each plot and the number of plants covered therein was counted. The process was repeated five times and the average number of flowered plants per plot computed. The process was further repeated every after two days until $50 \%$ flowering was achieved. On the other hand, finger millet plant height was measured at harvesting (75 DAS). The five plants used for the assessment of tillers and growth vigor were also used for this parameter. Plant height was taken from the stem base up to the finger millet head, using a meter rule. The average plant height per plot was then determined.

Time to physiological maturity of finger millet was determined starting from when the crop was at $50 \%$ maturity. A Quadrant of $1 \times 1 \mathrm{~m}$ was randomly thrown within the inner rows of each plot. All the finger millet plants within the quadrant were counted and the ratio of mature plants to non-mature plants determined. The process was repeated four times and the average number of mature plants per plot computed. The process was further repeated every after four days until $95 \%$ crop maturity was achieved (Wanyera, 2007). To establish physiological maturity, grain color change from green to brown and drying of old leaves were used the key indicators (Rebetzkeaf et al., 2012).

Weed population density, species' diversity and biomass were also evaluated. Weed population density was determined in situ using a quadrant $(1 \times 1 \mathrm{~m})$ randomly placed three times within each plot. The average population density per quadrant was computed, and the value subsequently extrapolated to $\mathrm{kg} \mathrm{ha}^{-1}$ per plot. Weed population density was determined at 20 and 60 days after sowing (DAS). Also Grain yield was assessed at physiological maturity. This involved harvesting of finger millet heads from the inner six rows out of ten rows per plot, excluding five plants at the extreme ends of each row. Harvesting was done using a knife. Harvested finger millet heads were sun-dried for four days. Thereafter, finger millet heads were threshed and winnowed to obtain grain yield per plot. Grain weight was recorded per plot using digital balance adjusted to 0.01 decimal points.

\subsection{Data Analysis}

Recorded data were subjected to analysis of variance (ANOVA) using Genstat statistical package $14^{\text {th }}$ edition. The means were compared using the least significant difference (LSD) test at $\mathrm{p} \leq 0.05$. Correlation analysis was performed to determine the relationship between fertilizers micro-dosing and weed biomass, weed diversity and weed population.

\section{Results}

\subsection{Fertilizer Micro-dosing Versus Weeding Time}

\subsubsection{Tiller Number}

There was a significant $(\mathrm{P}<0.05)$ interaction between $\mathrm{N}$ and $\mathrm{P}$ micro dose, and weeding time $(20 \mathrm{DAS}$ and double weeding) on tillering of finger millet (Table 1). The highest tiller number (3.52) was obtained when full dose of $\mathrm{N}\left(83 \mathrm{~kg} \mathrm{ha}^{-1}\right)$ and $\mathrm{P}\left(52 \mathrm{~kg} \mathrm{ha}^{-1}\right)$ were applied with double weeding at 20 and 45 DAS followed by $\mathrm{N}$ $\left(16.6 \mathrm{~kg} \mathrm{ha}^{-1}\right)$ and $\mathrm{P}\left(10.6 \mathrm{~kg} \mathrm{ha}^{-1}\right)$ with corresponding tiller number of 3.50. The lowest tiller number (mean of 2.23) was obtained with no fertilizer control across the weeding time. 
Table 1. Tillering response to interaction between fertilizer rates and time of weeding on finger millet production in eastern Uganda

\begin{tabular}{lllll}
\hline \multirow{2}{*}{ Micro-dosing rates $\left(\mathbf{k g ~ h a}^{\mathbf{- 1}}\right)$} & \multicolumn{3}{c}{ Time of weeding } \\
\cline { 2 - 5 } & 20 DAS & 30 DAS & 45 DAS & Double weeding $^{\mathrm{b}}$ \\
\hline $\mathrm{N}_{16.6} \mathrm{P}_{10.6}$ & 2.72 & 1.58 & 2.13 & 3.50 \\
$\mathrm{~N}_{16.6}$ & 2.48 & 2.62 & 2.00 & 2.95 \\
$\mathrm{P}_{10.6}$ & 2.70 & 1.67 & 2.22 & 2.55 \\
$\mathrm{~N}_{0} \mathrm{P}_{0}$ & 3.03 & 1.6 & 2.2 & 2.08 \\
$\mathrm{~N}_{83} \mathrm{P}_{52}{ }^{2}$ & 3.23 & 2.5 & 2.76 & 3.52 \\
\hline LSD (0.05) & $0.88^{*-}$ & $\mathrm{NS}$ & $\mathrm{NS}$ & $122^{*}$ \\
C.V. (\%) & 26.2 & 58.8 & 38.9 & 35.10 \\
\hline
\end{tabular}

Note. $\overline{\mathrm{DAS}}=$ Days after Sowing; ${ }^{*}=$ significant at $0.05 ; \mathrm{b}=$ weeding twice at 20 and $45 \mathrm{DAS} ; \mathrm{a}=$ Full $\mathrm{N}$ and $\mathrm{P}$ Dose used as check; NS = not significant.

\subsubsection{Growth Vigor}

The interaction between fertilizer micro-dosing and weeding time significantly $(\mathrm{P}<0.05)$ increased finger millet growth vigor at $20 \mathrm{DAS}$ and 30DAS weeding. In parallel, there was no significant difference $(\mathrm{P}>0.05)$ for finger millet growth vigor at 45 DAS and double weeding (20 and 45 DAS) affect. On the other hand, N and P micro dosing $\left(16.6 \mathrm{~kg} \mathrm{~N} \mathrm{ha}^{-1}\right.$ and $\left.10.6 \mathrm{~kg} \mathrm{P} \mathrm{ha}^{-1}\right)$ performed similarly to full dose fertilizer application $(83 \mathrm{~kg} \mathrm{~N}$ $\mathrm{ha}^{-1}$ and $52 \mathrm{~kg} \mathrm{P} \mathrm{ha}^{-1}$ ) across all weeding times (Table 3). A combination of $\mathrm{N}$ and P fertilizer micro dose had a superior effect on finger millet growth vigor performance over sole $\mathrm{P}$ and sole $\mathrm{N}$ fertilizer micro dose across all weeding times. Overall, interaction between weeding at 20 and 30 DAS and a combination of N and P fertilizer micro dosing and full fertilizer doses recorded the highest growth vigor score (4.0).

Table 2. Interaction effect between fertilizer rates and time of weeding on finger millet growth vigor in eastern Uganda

\begin{tabular}{lllll}
\hline \multirow{2}{*}{ Micro-dosing rates $\left(\mathbf{k g ~ h a}^{\mathbf{- 1}}\right)$} & \multicolumn{3}{c}{ Time of weeding } \\
\cline { 2 - 5 } & $20 \mathrm{DAS}$ & $30 \mathrm{DAS}$ & $45 \mathrm{DAS}$ & Double weeding $^{\mathrm{b}}$ \\
\hline $\mathrm{N}_{16.6} \mathrm{P}_{10.6}$ & 4.00 & 3.50 & 3.00 & 3.83 \\
$\mathrm{~N}_{16.6}$ & 3.17 & 2.83 & 2.50 & 3.17 \\
$\mathrm{P}_{10.6}$ & 3.33 & 3.00 & 2.50 & 3.33 \\
$\mathrm{~N}_{0} \mathrm{P}_{0}$ & 3.33 & 2.83 & 2.17 & 3.00 \\
$\mathrm{~N}_{83} \mathrm{P}_{52}{ }^{\mathrm{a}}$ & 3.97 & 4.00 & 3.00 & 3.92 \\
\hline LSD (0.05) & $0.65^{*-1}$ & $0.795^{* *-*^{*}}$ & $\mathrm{NS}$ & $\mathrm{NS}$ \\
C.V. (\%) & 15.4 & 20.7 & 32.1 & 17.6 \\
\hline
\end{tabular}

Note. $\mathrm{DAS}=$ Days after Sowing; $*=$ significant at $0.05 ; * *=$ significant at $0.01 ; \mathrm{b}=$ weeding twice at 20 and 45 DAS; $\mathrm{a}=$ Full $\mathrm{N}$ and $\mathrm{P}$ Dose used as check; NS = not significant.

\subsubsection{Weed Biomass}

The interactive effect between the $\mathrm{N}$ and $\mathrm{P}$ fertilizer micro dosing and time of weeding significantly $(\mathrm{P}<0.05)$ influenced weed biomass (Table 4). The combination of $\mathrm{N}$ and $\mathrm{P}\left(16.6 \mathrm{~kg} \mathrm{~N} \mathrm{ha}^{-1}\right.$ and $\left.10.6 \mathrm{~kg} \mathrm{P}^{-1}\right)$ application performed superiorly to sole $\mathrm{N}$ and sole $\mathrm{P}$ micro doses; and full dose of $\mathrm{N}$ and $\mathrm{P}$ in suppressing weed biomass, across all weeding times. Overall, $\mathrm{N}$ and $\mathrm{P}$ fertilizer micro dose together with weeding at $45 \mathrm{DAS}$, had the lowest weed biomass; while a combination of $\mathrm{N}$ and $\mathrm{P}$ full dose $\left(83 \mathrm{~kg} \mathrm{~N}^{-1}\right.$ and $\left.52 \mathrm{~kg} \mathrm{P}^{-1}\right)$ generally recorded the highest weed biomass a cross all the weeding times. This was followed by no fertilizer (Table 3 ). 
Table 3. Interaction effect between fertilizer rates and time of weeding on weed biomass in semi-arid regions in Eastern Uganda

\begin{tabular}{|c|c|c|c|c|}
\hline \multirow{2}{*}{ Micro-dosing rates $\left(\mathrm{kg} \mathrm{ha}^{-1}\right)$} & \multicolumn{4}{|c|}{ Time of weeding } \\
\hline & $20 \mathrm{DAS}$ & $30 \mathrm{DAS}$ & 45 DAS & Double weeding $^{\mathrm{b}}$ \\
\hline $\mathrm{N}_{16.6} \mathrm{P}_{10.6}$ & $8.3 \times 10^{-4}$ & $9.8 \times 10^{-4}$ & $7.7 \times 10^{-4}$ & $9.0 \times 10^{-4}$ \\
\hline $\mathrm{N}_{16.6}$ & $1.3 \times 10^{-3}$ & $8.8 \times 10^{-4}$ & $1.6 \times 10^{-3}$ & $8.2 \times 10^{-3}$ \\
\hline $\mathrm{P}_{10.6}$ & $1.8 \times 10^{-3}$ & $1.6 \times 10^{-3}$ & $1.6 \times 10^{-3}$ & $1.7 \times 10^{-4}$ \\
\hline $\mathrm{N}_{0} \mathrm{P}_{0}$ & $7.5 \times 10^{-4}$ & $1.1 \times 10^{-3}$ & $1.1 \times 10^{-3}$ & $9.8 \times 10^{-4}$ \\
\hline $\mathrm{N}_{83} \mathrm{P}_{52}{ }^{\mathrm{a}}$ & $2.0 \times 10^{-3}$ & $1.6 \times 10^{-3}$ & $1.9 \times 10^{-3}$ & $1.8 \times 10^{-3}$ \\
\hline LSD (0.05) & $3.6 \times 10^{-4 * * *}$ & $3.7 \times 10^{-4^{* * *}}$ & $4.3 \times 10^{-4 * \bar{*} *}$ & $4.4 \times 10^{-4 * * *}$ \\
\hline C.V. $(\%)$ & 22.3 & 25.1 & 25.8 & 29.9 \\
\hline
\end{tabular}

Note. DAS $=$ Days after sowing; $* *=$ significant at $0.01 ; * * *=$ significant at $0.001 ; \mathrm{b}=$ weeding twice at 20 and 45 DAS; $\mathrm{a}=$ Full $\mathrm{N}$ and P Dose used as check; NS = not significant.

\subsubsection{Correlation Between Nutrient Use Efficiency and Weed Biomass}

There was a very strong positive association between grain yield and nutrient use efficiency (NUE) $(\mathrm{P}<0.001)$. However, the association between weed biomass and NUE was negative, indicating that as weed biomass increases, NUE decreases and viza viz (Table 4). Time of weeding also had a negative relationship with nutrient use efficiency.

Table 4. Relationship between weed biomass and nutrient use efficiency in finger millet production in eastern Uganda

\begin{tabular}{|c|c|c|c|c|}
\hline & & NUE & Grain yield $\left(\mathrm{kg} \mathrm{ha}^{-1}\right)$ & Weeding regime weed dry weight $\left(\mathrm{kg} \mathrm{ha}^{-1}\right)$ \\
\hline \multirow{2}{*}{ Grain yield $\left(\mathrm{kg} \mathrm{ha}^{-1}\right)$} & Pearson correlation & 0.652 & & \\
\hline & P-Value & 0.000 & & \\
\hline \multirow{2}{*}{ Time of weeding } & Pearson correlation & -0.013 & 0.005 & \\
\hline & P-Value & 0.932 & 0.955 & \\
\hline \multirow{2}{*}{ Weed dry weight $\left(\mathrm{kg} \mathrm{ha}^{-1}\right)$} & Pearson correlation & -0.470 & 0.130 & 0.088 \\
\hline & P-Value & 0.001 & 0.157 & 0.338 \\
\hline
\end{tabular}

\subsubsection{Days to $50 \%$ Flowering}

The interaction effect of fertilizer micro-dosing with time of weeding on days to $50 \%$ flowering (Table 5) was significant $(\mathrm{P}<0.05)$, when finger millet was weeded at 20 DAS and double weeding (20 and 45 DAS). However, there was no significant interaction effect for weeding at 30 and 45 DAS on days to $50 \%$ finger millet flowering. The effect of $\mathrm{N}$ and P micro dose $\left(16.6 \mathrm{~kg} \mathrm{~N} \mathrm{ha}^{-1}\right.$ and $\left.10.6 \mathrm{~kg} \mathrm{P} \mathrm{ha}^{-1}\right)$ on days to finger flowering did not differ from that of their full doses $\left(83 \mathrm{~kg} \mathrm{~N}^{-1}\right.$ and $\left.52 \mathrm{~kg} \mathrm{P} \mathrm{ha}^{-1}\right)$. Interaction between fertilizer micro dosing with weeding at 20 DAS had the lowest time to flowering (53.82 days); while P micro dose (10.6 kg P ha $\left.{ }^{-1}\right)$ took the longest time to flowering ( 55.23 days) followed by no fertilizer application treatment ( 55.15 days). Overall, single weeding effect did not differ from that of double weeding. 
Table 5. Fertilizer micro-dosing effect and time of weeding on finger millet days to $50 \%$ flowering in eastern Uganda

\begin{tabular}{lllll}
\hline \multirow{2}{*}{ Micro-dosing rates $\left(\mathbf{k g ~ h a}^{\mathbf{- 1}}\right)$} & \multicolumn{3}{c}{ Time of weeding } \\
\cline { 2 - 5 } & 20 DAS & 30 DAS & 45 DAS & Double weeding $^{\mathrm{b}}$ \\
\hline $\mathrm{N}_{16.6} \mathrm{P}_{10.6}$ & 52.2 & 53.3 & 54.0 & 52.2 \\
$\mathrm{~N}_{16.6}$ & 54.3 & 54.5 & 55.0 & 55 \\
$\mathrm{P}_{10.6}$ & 54.6 & 54.8 & 56.7 & 54.8 \\
$\mathrm{~N}_{0} \mathrm{P}_{0}$ & 55.2 & 54.3 & 55.7 & 55.4 \\
$\mathrm{~N}_{83} \mathrm{P}_{52}{ }^{a}$ & 52.8 & 52.8 & 54.8 & 52.9 \\
\hline LSD (0.05) & $2.2^{*^{*}}$ & $\mathrm{NS}$ & $\mathrm{NS}$ & $2.2^{{ }^{-}}$ \\
C.V. (\%) & 3.4 & 4.9 & 4.9 & 3.4 \\
\hline
\end{tabular}

Note. $\mathrm{DAS}=$ Days after sowing; $*=$ significant at $0.05 ; \mathrm{b}=$ weeding twice at 20 and $45 \mathrm{DAS} ; \mathrm{a}=$ Full $\mathrm{N}$ and $\mathrm{P}$ Dose used as check; NS = not significant.

\subsubsection{Grain Yield}

The interaction between timing of weeding and fertilizer rates significantly $(\mathrm{P}<0.05)$ increased grain yield irrespective of weeding time (Table 6). The highest grain yield $\left(2292 \mathrm{~kg} \mathrm{ha}^{-1}\right)$ was obtained when weeding at 20 days after sowing (DAS) coupled with application of $\mathrm{N}$ and $\mathrm{P}$ as a micro dose at a rate of 16.6 and $10.6 \mathrm{~kg} \mathrm{ha}^{-1}$ was used. This was followed by full dose $\left(83 \mathrm{~kg} \mathrm{~N} \mathrm{ha}^{-1}\right.$ and $\left.52 \mathrm{~kg} \mathrm{p} \mathrm{ha}^{-1}\right)$ fertilizer application that gave grain yield of $2268 \mathrm{~kg} \mathrm{ha}^{-1}$ when single weeding was done at 45 DAS. Generally, weeding at 20 DAS was superior to all other weeding times (regimes) across all fertilizer rates, this was followed by weeding once at 45 and 30 DAS respectively. On the other hand, $\mathrm{P}$ application consistently supported superior grain yields to $\mathrm{N}$ application, irrespective of weeding time.

Table 6. Interaction effect between fertilizer rates and timing of weeding on finger millet grain yield in eastern Uganda

\begin{tabular}{|c|c|c|c|c|}
\hline \multirow{2}{*}{ Micro-dosing rates $\left(\mathrm{kg} \mathrm{ha}^{-1}\right)$} & \multicolumn{4}{|c|}{ Time of weeding } \\
\hline & $20 \mathrm{DAS}$ & $30 \mathrm{DAS}$ & $45 \mathrm{DAS}$ & Double weeding $^{b}$ \\
\hline $\mathrm{N}_{16.6} \mathrm{P}_{10.6}$ & 2292.0 & 2159.0 & 2021.0 & 2254.0 \\
\hline $\mathrm{N}_{16.6}$ & 1404.0 & 1280.0 & 1384.0 & 1404.0 \\
\hline $\mathrm{P}_{10.6}$ & 1696.0 & 1632.0 & 1718.0 & 1617.0 \\
\hline $\mathrm{N}_{0} \mathrm{P}_{0}$ & 1056.0 & 994.0 & 907.0 & 846.0 \\
\hline $\mathrm{N}_{83} \mathrm{P}_{52}{ }^{\mathrm{a}}$ & 2134.0 & 2194.0 & 2268.0 & 2012.0 \\
\hline LSD $(0.05)$ & $351.5^{* * * *}$ & & & \\
\hline C.V. $(\%)$ & 36.9 & & & \\
\hline
\end{tabular}

Note. DAS = Days after sowing; ${ }^{* * *}=$ significant at $0.001 ; \mathrm{b}=$ weeding twice at 20 and 45 DAS; $\mathrm{a}=$ Full $\mathrm{N}$ and P Dose used as check; NS = not significant.

\section{Discussion}

\subsection{Tiller Number and Growth Vigor}

The significant $(\mathrm{P}<0.05)$ increase in tillering (Table 1) when $\mathrm{N}$ and $\mathrm{P}$ was applied, either in micro doses or full dose, along with selected weeding time implies that there is need for reconciliation of plant nutrition and competition with weeds. Weeds are a bottle neck in the production of finger millet in the study and their effect has been underscored particularly when soil fertility is low (Asargew \& Shibabawu, 2014; Knight et al., 2017). Weeds are more competitive than the crops because they are more adapted to the field conditions than the introduced crop due to its desirable traits. Timing of weeding is important in order to strike the point at which the competition for resources (nutrients, light and moisture) between the crop and the weeds tend to be maximum. It is also important to perform optimal weeding, as excessive weeding encroaches on the profits expected from the crop (Kidoido et al., 2002). Also, optimal weeding ensures that the ground surface does not remain bare and exposed to soil erosion. The fact that micro doses of $\mathrm{N}$ and $\mathrm{P}$ led to similar levels of tillering, to full dose of $\mathrm{N}$ and $\mathrm{P}$ irrespective of weeding time, implies that farmers can save greatly by applying micro dose without losing on tillering which is a trait directly associated with grain yield. 
Weeding at 20 DAS is critical for P nutrition (Ekwangu et al., 2020), Phosphorus nutrition is often maximum in the early stages of plant growth (Grant, Flaten, Tomasiewicz, \& Sheppard, 2001). A similar observation was made by Knight et al. (2017) who noted tillering to be affected when early weed control was not done. Furthermore, Hasan and Ismail (2016) reported an increase in plant height, number of nodules per plant, number of pods per plant, pod yield $\left(\mathrm{kg} \mathrm{ha}^{-1}\right)$, seed weight, oil content and shelling percentage in groundnuts production when $\mathrm{P}$ was applied at 7 DAS. It is also during this stage that the plant accumulates biomass, which is subsequently translocated to form grain yield (Kamara et al., 2014). In fact, Asargew and Shibabawu (2014) noted weed competition to fall between 20 and 30 DAS within which competition for nutrients between crops and weeds would be high and greatly affecting tillering and growth vigor if not managed. On the other hand, weeding at 45 days after sowing (DAS) is important because it is a period where $\mathrm{N}$ is maximally needed for flowering and grain filling (Ali, 2010). Ayub et al. (2009) also reported an increase in tiller number when $\mathrm{N}$ was applied in a weed free condition. A similar pattern was observed in this current study for growth vigor, and tillering. In addition, both tillering and growth vigor have been reported to be influenced by amount of $\mathrm{N}$ and $\mathrm{P}$ fertilizer applied especially, when spot application of $\mathrm{N}$ and $\mathrm{P}$ fertilizer micro dosing is conducted (ICRISAT, 2013). This could be used to explain why there was increase in tiller number and growth vigor when $\mathrm{N}$ and $\mathrm{P}$ fertilizer micro-dose was applied, and low tillering recorded with no fertilizer.

\subsection{Weed Biomass}

The significant reduction in weed biomass due to $\mathrm{N}$ and $\mathrm{P}$ fertilizer micro dosing across weeding regimes is a positive development, which can be explained by the possibility that spot application of the fertilizer close to the crop rows benefited the crop more than the weeds (Kamara et al., 2014; Knight et al., 2017). Therefore, micro dosing together with strategic fertilizer placement can be used as a weed control approach that can be exploited further by farmers to minimize labor costs as well as boost profits accruing from finger millet production. In fact, (ICRISAT, 2013) reported fertilizer micro dosing to increase maize yield by $25-50 \%$ and profitability of the crop in the Sahel region in West Africa. There is, however, need for further studies to refine this approach particularly in the context of profitability. The low weed biomass accruing from fertilizer micro dosing is, therefore, associated with the small amount of fertilizer (micro dose) and close fertilizer application to the crop rows which often tend to benefit the crop more than the weeds (Ouattara et al., 2017).

The superior performance of $\mathrm{N}$ and $\mathrm{P}$ micro dose combination in suppressing weeds over sole $\mathrm{N}$ and $\mathrm{P}$ micro doses respectively is associated with the interactive effect of $\mathrm{N}$ and $\mathrm{P}$ on plant growth. Nitrogen is a component of amino acids whose role among others is repair of damaged plant tissues and contributes to general plant growth through facilitation of cell division. On the other hand, $\mathrm{P}$ is a major component of Adenosine Triphosphate (ATP) which provides energy for plant metabolism (Wafula et al., 2016). The interactive effect of $\mathrm{N}$ and $\mathrm{P}$ stated above could have caused vigorous growth of finger millet. The fairly vigorous growth that occurred, could have led to the suppression of weeds in addition to denial of nutrients for the weeds in favor of the crop.

The high weed biomass observed with the full dose of $\mathrm{N}$ and P fertilizer (Table 3) could be evidence that high rates of nitrogen promote weed proliferation. Weeds are usually more aggressive in the weed-crop competitions for resources, especially under plentiful supply of nitrogen (Knight et al., 2017). Ugen et al. (2002) and Rahnavard et al. (2009) also observed increased weed population density with increase in NPK fertilizer application. The full dose of $\mathrm{N}$ and $\mathrm{P}$, apart from promoting weed biomass and its negative effects on the crop, also pose a potential impact on the environment. This is so because it is most unlikely that, all the nutrients released by the full dose were intercepted by both the crop and the weeds. It is, therefore, imperative that low cost strategies for managing weeds, such as nutrient micro dosing should be mainstreamed within research and crop production activities, especially in finger millet which is currently defined by weed management constraints in Uganda

\subsection{Days to $50 \%$ Flowering}

The significant reduction in days to $50 \%$ flowering with $\mathrm{N}$ and $\mathrm{P}$ fertilizer micro dosing and either single weeding at 20 DAS and double weeding at 20 and 45 DAS is evidence that $\mathrm{N}$ and P are limiting nutrient and that finger millet requires early weed control. Furthermore, the reduction in days to $50 \%$ flowering by three and two days when finger millet was micro dosed with a combination of $\mathrm{N}$ and $\mathrm{P}$ micro dose $\left(16.6 \mathrm{~kg} \mathrm{~N} \mathrm{ha}^{-1}\right.$ and $10.6 \mathrm{~kg}$ $\mathrm{P} \mathrm{ha}^{-1}$ ) and weeding at 20 DAS; and double weeding at 20 and 45 DAS respectively is evidence that early weed control in finger millet was necessary in order to minimize competition for nutrients by weeds (Kamara et al., 2014; Menegat \& Nilsson, 2019). This enables the crop to maximally utilize the $\mathrm{N}$ and P fertilizer micro dose applied. 
On the other hand, double weeding performed similar to single weeding at 20 DAS. This is suggestive that weeding the second time at 45 DAS did not have significant influence on days to $50 \%$ flowering. These observations conforms to earlier observations by Asargew and Shibabawu (2014) who noted that there was delayed finger millet growth when weeding was delayed; and the critical weed competition period was observed between 20 and 45 DAS. Knight et al. (2017) also noted that early removal of weeds reduced N absorption by weeds and that critical weed competition period was between 20 and 45 DAS.

The similar performance between the combination of $\mathrm{N}$ and $\mathrm{P}$ micro dose $\left(16.6 \mathrm{~kg} \mathrm{~N} \mathrm{ha}^{-1}\right.$ and $\left.10.6 \mathrm{~kg} \mathrm{Pha}^{-1}\right)$ and full doses $\left(83 \mathrm{~kg} \mathrm{~N} \mathrm{ha}^{-1}\right.$ and $\left.52 \mathrm{~kg} \mathrm{Pha}^{-1}\right)$ across all weeding times is suggestive that full dose application was in excess of what finger millet (SEREMI II variety) requires for its growth; It can, therefore, be concluded that a combination of weeding once at $20 \mathrm{DAS}$ and $\mathrm{N}$ and P micro dose $\left(16.6 \mathrm{~kg} \mathrm{~N} \mathrm{ha}^{-1}\right.$ and $10.6 \mathrm{~kg} \mathrm{P}^{-1}$ is superior to all other weeding and fertilizer combinations for reduction in days to $50 \%$ flowering.

\subsection{Finger Millet Grain Yield}

The superior grain yield obtained from weeding at 20 DAS, across fertilizer micro doses over other weeding times suggests that weeding at 20 DAS is critical in finger millet production. In the early stages (10-30 DAS) of finger millet growth, the crop is often susceptible to suppression from light and nutrient by weeds due to the latter's aggressiveness in extracting nutrients from soil and intercepting light from the sun. It, therefore, becomes prudent to manage weeds at this early stage of finger millet growth. Asargew and Shibabawu (2014) also, noted that critical weed competition period falls between 20 and 45 DAS. This is the period in the finger millet crop growth cycle where weed free conditions are necessary for the crop to sufficiently receive light and nutrients for its growth and development of storage organs (grain). The generally poor grain yield performance observed when double weeding (20 and 45 DAS) of finger millet was done across all fertilizer micro doses, is attributed to mechanical damage of roots during late weeding as a result of hand hoeing. This could have caused impairment of nutrient uptake by finger millet crop in its critical time of growth. During the healing process of damaged roots, nutrient uptake and growth may have been affected. Patil and Reddy (2014), Similarly reported that mechanical weed control caused crop injury, especially the roots and the stems when weeding was done late causing reduction in growth during the healing period.

The superior performance of sole $\mathrm{P}$ micro dose across weeding times over $\mathrm{N}$ fertilizer micro dose suggests $\mathrm{P}$ as the most limiting nutrient in the study soil and further underscores the function of $\mathrm{P}$ in crop and grain development. Moreover, P is a major component of ATP, a contributor of energy necessary for photosynthesis and metabolic processes in the plant (Wafula et al., 2016). The role played by P directly translates to grain development and consequently high grain yield (Ndungu-Magiroi et al., 2017). This result is in agreement with the findings by (Opole, 2010) and (Kamara et al., 2014) who reported that nutrients especially NPK are required at the early flowering and grain filling stages of finger millet growth and therefore influence grain yield.

\section{Conclusion}

Fertilizer micro dosing of N and P (N $16.6 \mathrm{~kg} \mathrm{ha}^{-1}$ and P $\left.10.6 \mathrm{~kg} \mathrm{ha}^{-1}\right)$ reduced weed population and weed biomass in finger millet production compared to the full dose of $\mathrm{N}$ and $\mathrm{P}\left(\mathrm{N} 83 \mathrm{~kg} \mathrm{ha}^{-1}\right.$ and $\left.\mathrm{P} 52 \mathrm{~kg} \mathrm{ha}^{-1}\right)$.

Weeding once at 20 DAS is the most effective way of controlling weeds for increased finger millet grain yield in finger millet production.

A combination of weeding once (20 DAS) and fertilizer micro dosing ( $16.6 \mathrm{~kg} \mathrm{ha}^{-1}$ and P $10.6 \mathrm{~kg} \mathrm{ha}^{-1}$ ) enhances finger millet productivity in the semi-arid regions of eastern Uganda

\section{Recommendations}

Micro dosing (N $16.6 \mathrm{~kg} \mathrm{ha}^{-1}$ and P $10.6 \mathrm{~kg} \mathrm{ha}^{-1}$ ) and weeding once (20 DAS) should be practiced as a package to enhance soil fertility in finger millet production.

Farmers could weed finger millet once at 20 DAS for effective control of weeds in finger millet production.

\section{References}

Ali, E. A. (2010). Grain yield and nitrogen use efficiency of pearl millet as affected by plant density, nitrogen rate and splitting in sandy soil. American-Eurasian Journal of Agricultural and Environmental Science, 7, 327-335. Retrieved from http://www.idosi.org/aejaes/jaes7(3)/13.pdf

Asargew, F., \& Shibabawu, A. (2014b). Appropriate Time for Weed Management for Finger millet (Eleusin coracana Goartn). Journal of Natural Sciences Research, 4(16). 
Ayub, M., Nadeem, M. A., Tahir, M., Ibrahim, M., \& Aslam, M. N. (2009). Effect of nitrogen application and harvesting intervals on forage yield and quality of pearl millet (Pennisetum americanum L.). Pakistan Journal of Life and Social Sciences, 7(2), 185-188. Retrieved from http://agris.fao.org/agris-search/search. do?recordID=PK2010000272

Blackshaw, R. E., Brandt, R. N., Janzen, H. H., Entz, T., Grant, C. A., \& Derksen, D. A. (2003). Differential response of weed species to added nitrogen. Journal of Weed Science, 51, 532-539. https://doi.org/10.1614/ 0043-1745(2003)051[0532:DROWST]2.0.CO;2

Blackshaw, R. E., Semach, G., \& Janzen, H. H. (2002). Fertilizer application method affects nitrogen uptake in weeds and wheat. Journal of Weed Science, 50, 634-641. https://doi.org/10.1614/0043-1745(2002)050[0634: FAMANU]2.0.CO;2

Berkowitz, A. R. (1988). Competition for resources in weed-crop mixtures. In M. A. Altieri \& M. Liebman (Eds.), Weed Management in Agroecosystems: Ecological Approaches (pp. 89-119). Boca Raton, Florida, USA: CRC Press.

Ebanyat, P. (2009). A road to food? Efficacy of nutrient management options targeted to heterogeneous soilscapes in the Teso farming system, Uganda.

Ekwangu, J., Anguria, P., Andiku, C., Tenywa, J. S., Bisikwa, J., Wanyera, N., \& Ugen, M. A. (2020). Fertilizer Micro-dosing and Timing of Weeding for Enhancing Finger-Millet Production in Eastern Uganda. Journal of Agricultural Science, 12(11).

Esele, J. P. (1989). Sorghum and Millets Diseases. John Wiley \& Sons.

Grant, C. A., Flaten, D. N., Tomasiewicz, D. J., \& Sheppard, S. C. (2001). The importance of early season phosphorus nutrition. Canadian Journal of Plant Science, 81(2), 211-224. https://doi.org/10.4141/P00-093

Gupta, S., Gupta, S. M., Gupta, A. K., Gaur, V. S., \& Kumar, A. (2014). Fluctuation of Dof1/Dof2 expression ratio under the influence of varying nitrogen and light conditions: Involvement in differential regulation of nitrogen metabolism in two genotypes of finger millet (Eleusine coracana L.). Gene, 546(2), 327-335. https://doi.org/10.1016/j.gene.2014.05.057

Gupta, S. M., Arora, S., Mirza, N., Pande, A., Lata, C., Puranik, S., Kumar, J., \& Kumar, A. (2017). Finger Millet: A "Certain" Crop for an "Uncertain" Future and a Solution to Food Insecurity and Hidden Hunger under Stressful Environments. Frontiers in Plant Science, 8. https://doi.org/10.3389/fpls.2017.00643

Hasan, M., \& Ismail, S. B. (2016). Effects of phosphorous fertilizer on growth and yield of groundnut. AIP Conference Proceedings, 1784(1), 060018. https://doi.org/10.1063/1.4966856

Hatier, J.-H. B., Faville, M. J., Hickey, M. J., Koolaard, J. P., Schmidt, J., Carey, B.-L., \& Jones, C. S. (2014). Plant vigour at establishment and following defoliation are both associated with responses to drought in perennial ryegrass (Lolium perenne L.). Journal of Experimental Botany, 65(20), 5823-5834. https://doi.org/10.1093/jxb/eru318

Houghton Mifflin Co. (2007). The American Heritage medical dictionary. Houghton Mifflin Co.

ICRISAT. (2013). Annual report 2013. ISSUU. Retrieved from https://issuu.com/icrisat/docs/annual_ report_2013

Kamara, A. Y., Ewansiha, S. U., \& Menkir, A. (2014). Assessment of nitrogen uptake and utilization in drought tolerant and Striga resistant tropical maize varieties. Archives of Agronomy and Soil Science, 60(2), 195-207. https://doi.org/10.1080/03650340.2013.783204

Kidoido, M. M., Kasenge, V., Mbowa, S., Tenywa, J. S., \& Nyende, P. (2002). Socioeconomic factors associated with finger millet production in eastern Uganda. African Crop Science Journal, 10(1). https://doi.org/ 10.4314/acsj.v10i1.27561

Knight, A. M., Everman, W. J., Jordan, D. L., Heiniger, R. W., \& Smyth, T. J. (2017). Interactions of Nitrogen Source and Rate and Weed Removal Timing Relative to Nitrogen Content in Corn and Weeds and Corn Grain Yield. International Scholarly Research Notices, 2017, Article ID 8961367. https://doi.org/10.1155/ 2017/8961367

Menegat, A., \& Nilsson, A. T. S. (2019). Interaction of Preventive, Cultural, and Direct Methods for Integrated Weed Management in Winter Wheat. Agronomy, 9(9), 564. https://doi.org/10.3390/agronomy9090564 
Ndungu-Magiroi, K. W., Kasozi, A., Kaizzi, K. C., Mwangi, T., Koech, M., Kibunja, C. N., ... Wortmann, C. S. (2017). Finger millet response to nitrogen, phosphorus and potassium in Kenya and Uganda. Nutrient Cycling in Agroecosystems, 108(3), 297-308. https://doi.org/10.1007/s10705-017-9857-7

Okoboi, G., Muwanga, J., \& Mwebaze, T. (2012). Use of improved inputs and its effect on maize yield and profit in Uganda. African Journal of Food, Agriculture, Nutrition and Development, 12(7). Retrieved from https://www.ajol.info/index.php/ajfand/article/view/84204

Opole, R. A. (2010). Effect of environmental stress and management on grain and biomass yield of finger millet [Eleusine coracana L.) Gaertn.] (p. 201). Retrieved from http://search.proquest.com

Opole, R. A., Prasad, P. V. V., \& Staggenborg, S. A. (2013). Effect of seeding and nitrogen fertiliser application rates on field performance of finger millet. 11th African Crop Science Proceedings, Sowing Innovations for Sustainable Food and Nutrition Security in Africa, October 14-17, 2013, Entebbe, Uganda (pp. 127-135). Retrieved from https://www.cabdirect.org/cabdirect/abstract/20163288716

Ouattara, K., Serme, I., Bandaogo, A. A., Ouedraogo, S., Sohoro, A., Gnankambary, Z., Pare, T. (2017). Optimizing fertilizer use within an integrated soil fertility management framework in Burkina Faso. In C. S. Wortmann \& K. Sones (Eds.), Fertilizer use optimization in sub-Saharan Africa (pp. 40-51). CABI. https://doi.org/10.1079/9781786392046.0040

Owere, L., Tongoona, P., Derera, J., \& Wanyera, N. (2014). Farmers' Perceptions of Finger Millet Production Constraints, Varietal Preferences and Their Implications to Finger Millet Breeding in Uganda. Journal of Agricultural Science, 6(12), 126. https://doi.org/10.5539/jas.v6n12p126

Patil, B., \& Reddy, V. C. (2014). Weed management practices in irrigated organic finger millet (Eleusine coracana (L.) Gaertn.). Sch J Agric Vet Sci, 1(4A), 211-215.

Rahnavard, A., Ashrafi, Z. Y., Alizade, H. M., \& Sadeghi, S. (2009). Studies on the effect of fertilizer application and crop rotation on the weed infested fields in Iran. Journal of Agricultural Technology, 5(1), 41-50.

Rebetzkeaf, G., van Herwaardenb, A., Chenuc, K., Moellerd, C., Biddulphe, B., Richardsa, R., \& Ratteya, A. (2012). Protocols for experimental plot sampling, handling and processing of cereals in field experiments. Standardised Methods for Use in Large Agronomic, Physiological and Genetic Field Studies. Retrieved from https://docplayer.net/28884194-Protocols-for-experimental-plot-sampling-handling-and-processing-of -cereals-in-field-experiments.html

UBOS. (2010). UBOS Report 2010.

Ugen, M. A., Wien, H. C., \& Wortmann, C. S. (2002). Dry bean competitiveness with annual weeds as affected by soil nutrient availability. Weed Science, 50(4), 530-535. https://doi.org/10.1614/0043-1745(2002)050 [0530:DBCWAW]2.0.CO;2

Wafula, W. N., Korir, N. K., Ojulong, H. F., \& Gweyi-Onyango, J. P. (2016). Flowering and maturation periods of Finger Millet as influenced by phosphorus and variety in different agro-ecologies in Kenya (p. 5).

Wafula, W. N., Nicholas, K. K., Henry, O. F., \& Siambi, M. (2016). Finger millet (Eleusine coracana L.) grain yield and yield components as influenced by phosphorus application and variety in Western Kenya. Tropical Plant Research, 3(3), 673-680. https://doi.org/10.22271/tpr.2016.v3.i3.088

Wanyera, N. M. W. (2007). Finger-millet (Eleusine coracana (L.) Gaertn) in Uganda. Proceedings of the First International Finger Millet Stake-Holders Workshop, Projects R8030 \& 8445, UK Department for International Development—Crop Protection Programme Held on 13th-14th September 2005.

\section{Copyrights}

Copyright for this article is retained by the author(s), with first publication rights granted to the journal.

This is an open-access article distributed under the terms and conditions of the Creative Commons Attribution license (http://creativecommons.org/licenses/by/4.0/). 